\title{
Changes in the Editors' Team: Farewell to Greg Atkinson, Welcome to Keith Stokes
}

H.-J. Appell Coriolano

Bibliography

DOI http://dx.doi.org/ $10.1055 / \mathrm{s}-0034-1377010$

Int J Sports Med 2014; 35:

543 @ $)$ Georg Thieme

Verlag KG Stuttgart · New York

ISSN 0172-4622

Correspondence

Prof. Dr. Dr. h.c. Hans-Joachim

Appell Coriolano

Institut für Physiologie und

Anatomie

Deutsche Sporthochschule Köln

Tel.: + 49/221/49825430

Fax: $+49 / 221 / 49826790$

Appell@dshs-koeln.de
After our close and fruitful association with Professor Greg Atkinson as Editor of our journal, we are very sorry to announce that he will step down from this position. Professor Atkinson, who has been part of our core team since 2006, recently moved from a sports science department to a health and social care institute. In order to fully focus on the new challenges he is facing in this clinical context, he decided to lay down his work as an editor.

The IJSM editors have highly appreciated his contribution to the journal's success over the past 8 years. Alongside his excellent expertise in many fields, Professor Atkinson has been especially active within the Training \& Testing Section of IJSM. He has (co)authored significant editorials [1-3], all of which are compulsory reading for IJSM authors and define important standards of the journal. Greg's friendly and loyal collaboration within the team of editors and with Thieme Publishers was outstanding and will be sorely missed.

When looking for a successor, we considered various colleagues, all with excellent scientific records and reputations. After much discussion, we invited Dr. Keith Stokes from the University of Bath (UK) who accepted this position. Dr. Stokes has broad research interests in the field of Exercise Physiology and Sports Medicine and, moreover, is strongly linked to Sports Science through his significant expertise in rugby. We are sure that IJSM will benefit greatly through his involvement. We are looking forward to working with Dr. Stokes and warmly welcome him to our team.

Hans-Joachim Appell Coriolano for the Editors of the IJSM

\section{References}

1 Atkinson G, Pugh C, Scott MA. Exploring data distribution prior to analysis: benefits and pitfalls. Int J Sports Med 2010; 31: 841-842

2 Harriss DJ, Atkinson G. Ethical standards in sport and exercise science research: 2014 update. Int J Sports Med 2013; 34: 1025-1028

3 Stapleton C, Scott MA, Atkinson G. The 'so what' factor: statistical versus clinical significance. Int J Sports Med 2009; 30: 773-774 